\title{
Self-Rechargeable Battery Vehicle
}

\author{
Rajeeva HS, Manjunath MV, Dinakar. M, Gaurav Pandey
}

\begin{abstract}
Widespread adoption of electric vehicles will relieve us from problems such as environmental pollution, global warming and oil dependency. However, theusage of $\mathrm{EV}$ is relatively low in spite of many governments implementing strong promotion policies. This paper presents a understandable review of studies on consumer preferences for $\mathrm{EV}$, aiming to better inform policy-makers and give direction to further research. First, we compare the psychological and economic approach towards this topic, followed by a conceptual work of $E V$ preferences which is then implemented to organise our review. We also consider the modelling techniques applied in the selected studies. Estimates of consumer preferences for financial, technical, infrastructure and policy attributes are then considered. A categorisation of main factors for consumer preferences into groups such as socio-economic variables, psychological factors, mobility condition, social influence, etc. is then made and their impacts are briefly explained. Finally, we discuss a research agenda to improve EV consumer preference studies and give suggestions for further research.
\end{abstract}

Keywords: Electric vehicles, Comprehensive, Infrastructure, Psychological factors, Mobility condition.

\section{INTRODUCTION}

A battery electric vehicle (BEV) is a type of vehicle which uses chemical energy stored in rechargeable battery packs as energy source. They utilize all power from battery packs and thus have no internal combustion engine, fuel tank or fuel cell. Battery electric vehicles use electricity, which is stored in a battery pack to run the electric motor and hence the wheel rotates. When exhausted, the batteries are recharged using electricity from a allocated charging unit .The amount of pollution produced depends on how the electricity is produced. This unit consists of two 12-24 DC motors, one 8-12v DC motor and with pulleys and belt arrangement for power transmission.

The concept of battery electric vehicles is to use charged batteries onboard vehicles for transportation. Battery electric cars are becoming more and more attractive compared to higher oil prices and the development of new battery technology such as Lithium Ion batteries that have higher power and energy density compared to older battery types such as lead-acid batteries. Electric cars can outstandingly reduce city pollution by having zero tail pipe emissions. Vehicle greenhouse gas savings depend on how the electricity is produced. Using an electric car would result in reduction of carbon dioxide emissions Up to 30 percent.

Manuscript received on January 27, 2021.

Revised Manuscript received on February 22, 2021.

Manuscript published on February 28, 2021

Rajeeva HS, Asst.Prof, Department of mechanical engineering, DBIT, Bangalore, Karnataka, India. Email: hsjeevaraju @ gmail.com

Manjunath MV, Asst.Prof, Department of mechanical engineering, DBIT, Bangalore, Karnataka, India

Dinakar. M, Student, Department of mechanical engineering, DBIT, Bangalore, Karnataka, India

Gaurav Pandey, Student, Department of mechanical engineering, DBIT, Bangalore, Karnataka, India
Electric cars are having a major impact in the automobiles industry given advantages in city pollution, less dependence on oil and combustion and scarcity and expected rise in gasoline prices.

\section{METHODOLOGY}

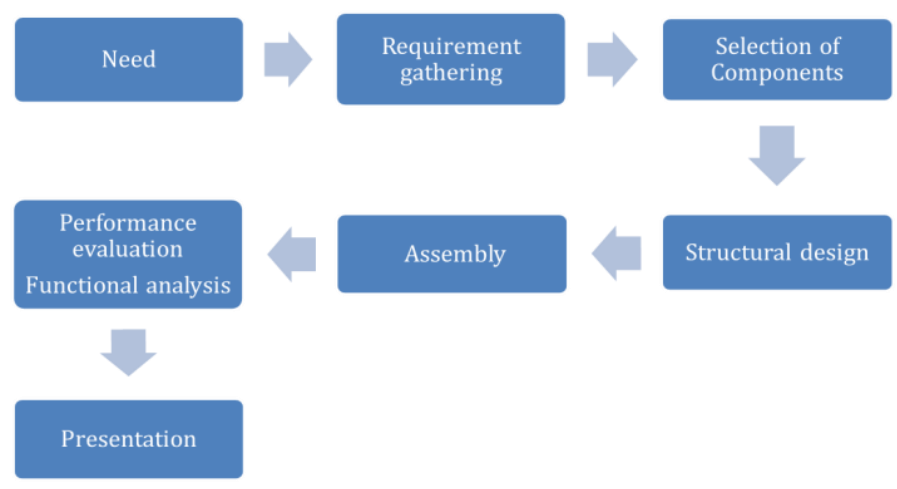

III. BLOCK DIAGRAM

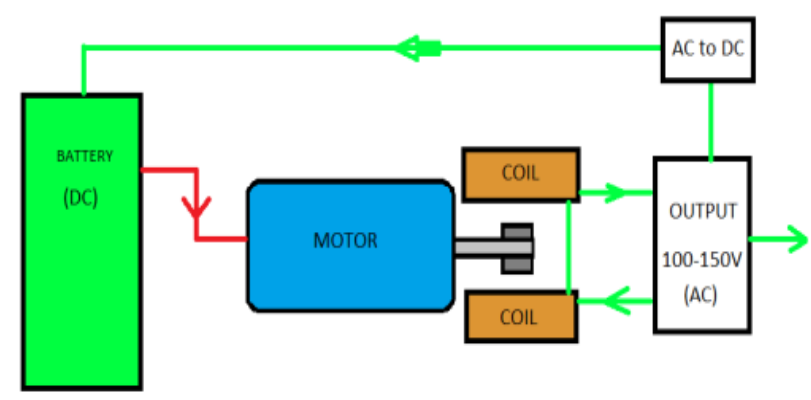

Fig 1: Block diagram of battery vehicle

In this block diagram the operation is carried out as follows. The motor runs by the power generated by the battery. The motor spindle consists of magnets and there are coils present at both sides of the magnets. When the magnet starts to rotate some amount of current is generated in the coils and the current is used to charge the battery. The components used in the construction are a $12 \mathrm{v}$ DC motor, a rechargeable battery, pulley and a V- belt. In this construction the DC motor is get electrical supply from the battery. The first motor shaft is connected with 60 teeth pulley to transmit power. This is called driver motor. The second motor shaft is connected with 20teeth pulley to get transmitted power from first motor. This motor is called driven motor. The $\mathrm{V}$ - belt is used to transmit power from driver motor to driven motor. The second motor is electrically connected to battery and the external load.

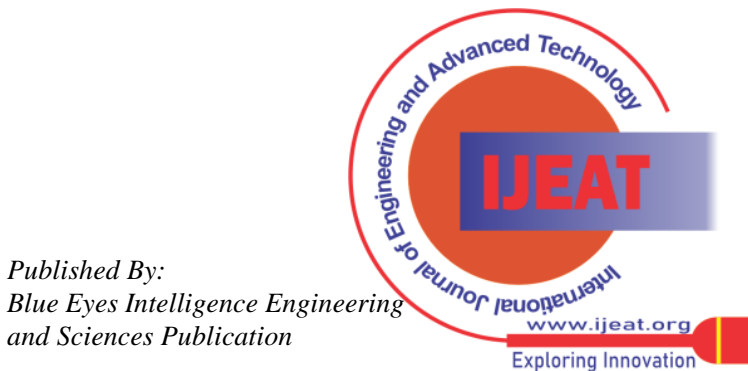




\section{Self-Rechargeable Battery Vehicle}

The power or electrical energy will be stored in the battery packs. This battery packs acts as primary power source of the system.

The power is supplied to driver motor using suitable electrical connections. When the power is the motor shaft starts rotates. Since shaft transmits motion to second motor with belt transmission, rotation of driver motor starts. As we know the driver motor have 60 teeth pulley and driven motor have 20 teeth pulley. The rotation of driven motor shat will be three times more compared to driver motor shaft rotation speed. The when second motor is supplied with kinetic energy or rotational energy, it starts acting as dynamo, hence it produces electrical energy. The electrical energy produced will be of more current and voltage than electrical energy supplied to driver motor due to more speed rotation of driven motor compared to driver motor.

This high power electrical energy is used as power supply to recharge the battery with provides power supply to driver motor. The excess electrical supply is used as power supply for external load.

\section{COMPONENTS SPECIFICATIONS}

\section{A. DC Motor}

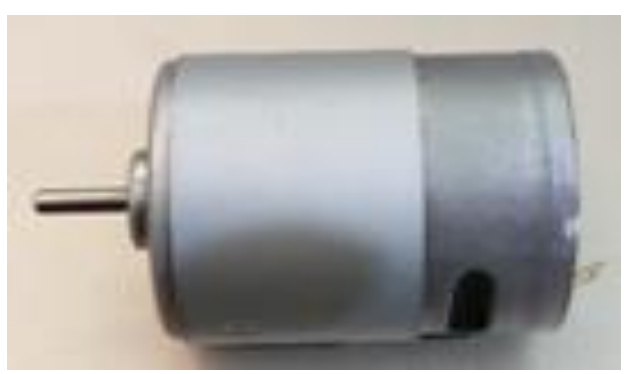

The motor that is used in this project is BLDC40S40A-12V Brushless DC motor. The dc motor is of $12 \mathrm{v}$ DC. This motor produces a continues torque of $2.65 \mathrm{In}-\mathrm{lbs}$ and also induces a current of 4.7 amps.

\section{B. 20 Teeth GT2 Pulley}
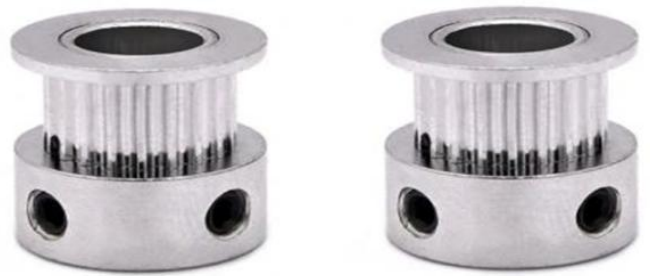

The pulley that is used in the project is a 20 teeth GT2 pulley. It consists of an inner and outer diameter of $8 \mathrm{~mm}$ and $16 \mathrm{~mm}$ respectively. The width of pulley is $16 \mathrm{~mm}$ and the weight is 8 gm.

\section{60 Teeth GT2 Pulley}

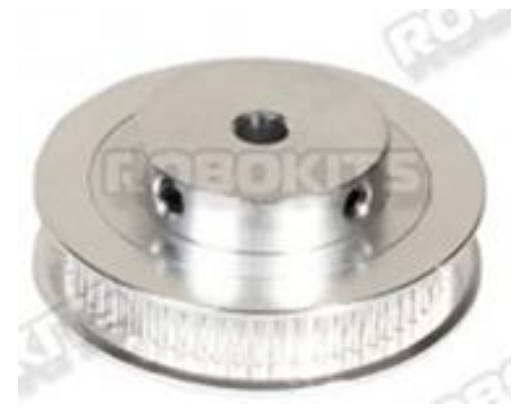

The other type of pulley that is used is 60 teeth GT2 pulley. This pulley consist of 60 teethes and material of the pulley is aluminum. The core diameter and the belt width of the pulley is $5 \mathrm{~mm}$ and $6 \mathrm{~mm}$ respectively.

\section{Cogged V-Belt}

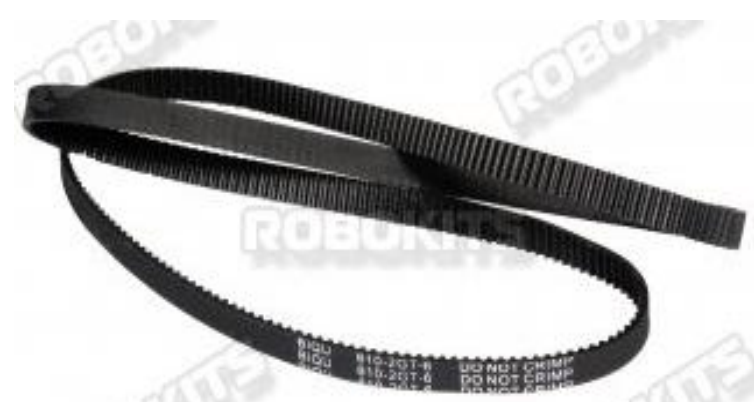

The type of belt that is used in the project is cogged v-belt This cogged v-belt is made up of Neoprene rubber and it is of $610 \mathrm{~mm}$ length. The pitch and the belt width of the belt is $2 \mathrm{~mm}$ and $6 \mathrm{~mm}$ respectively.

\section{E. Mounting Brackets}

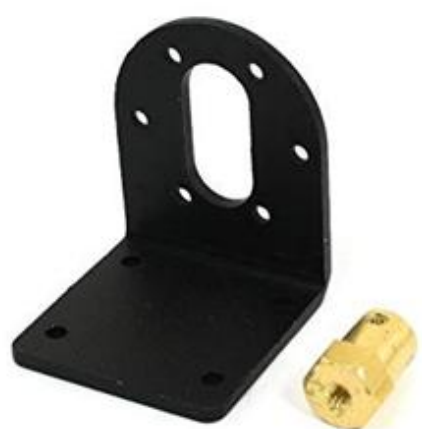

The material of this mounting bracket is metal which has a weight of $35 \mathrm{~g}$. The hole sizes in the bracket are of size $27 * 13 \mathrm{~mm}$.

\section{RESULTS AND DISCUSSION}

Table-I: 3V DC Motor

\begin{tabular}{|c|c|c|c|}
\hline $\begin{array}{c}\text { Speed } \\
(\mathbf{R P M})\end{array}$ & $\begin{array}{c}\text { Voltage } \\
(\mathbf{V})\end{array}$ & $\begin{array}{c}\text { Current } \\
(\mathbf{A})\end{array}$ & $\begin{array}{c}\text { Power } \\
\text { (W) }\end{array}$ \\
\hline At $2500 \mathrm{rpm}$ & 3 & 0.15 & 0.45 \\
\hline At $5100 \mathrm{rpm}$ & 3 & 0.32 & 0.96 \\
\hline At $9000 \mathrm{rpm}$ & 3 & 0.4 & 1.2 \\
\hline At $17000 \mathrm{rpm}$ & 3 & 0.47 & 1.41 \\
\hline
\end{tabular}

Table-II: 6V DC Motor

\begin{tabular}{|c|c|c|c|}
\hline $\begin{array}{c}\text { Speed } \\
(\text { RPM })\end{array}$ & $\begin{array}{c}\text { Voltage } \\
(\mathbf{V})\end{array}$ & $\begin{array}{c}\text { Current } \\
(\mathbf{A})\end{array}$ & $\begin{array}{c}\text { Power } \\
(\mathbf{W})\end{array}$ \\
\hline At $2500 \mathrm{rpm}$ & 6 & 0.018 & 0.108 \\
\hline At $5100 \mathrm{rpm}$ & 6 & 0.037 & 0.222 \\
\hline At $9000 \mathrm{rpm}$ & 6 & 0.12 & 0.72 \\
\hline
\end{tabular}

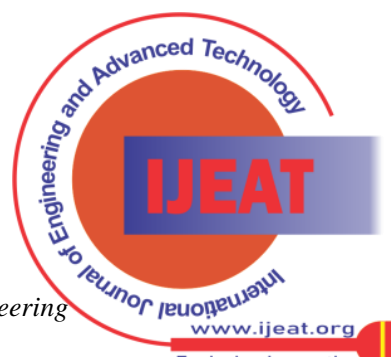




\begin{tabular}{|c|c|c|c|}
\hline At 17000 rpm & 6 & 0.23 & 1.38 \\
\begin{tabular}{|c|c|c|c|}
\hline \multicolumn{4}{|c|}{ Table-III: 9V DC Motor } \\
(RPM)
\end{tabular} & $\begin{array}{c}\text { Voltage } \\
\text { (V) }\end{array}$ & $\begin{array}{c}\text { Current } \\
\text { (A) }\end{array}$ & $\begin{array}{c}\text { Power } \\
\text { (W) }\end{array}$ \\
\hline At $2500 \mathrm{rpm}$ & 9 & 0.18 & 1.62 \\
\hline At $5100 \mathrm{rpm}$ & 9 & 0.22 & 1.98 \\
\hline At $9000 \mathrm{rpm}$ & 9 & 0.29 & 2.61 \\
\hline At $17000 \mathrm{rpm}$ & 9 & 0.48 & 4.32 \\
\hline
\end{tabular}

from $4 \mathrm{w}$ to $5 \mathrm{w}$, and then from increase in voltage there is also increase in power up to $12 \mathrm{w}$ and then the power value drops and the gradually increases for the minimum current.

\section{CONCLUSION}

Battery electric vehicles are definitely more eco-friendly compared to internal-combustion vehicles. Batteries are being engineered to have high durability. When the battery electric cars become more widespread, battery recycling will be economically possible. Research into other energy sources such as renewable fuels and fuel cells make the future look brighter for battery electric vehicles. Our project of more battery electric vehicles depends on motor specifications that

Table-IV: 12V DC Motor

\begin{tabular}{|c|c|c|c|}
\hline $\begin{array}{c}\text { Speed } \\
(\mathbf{R P M})\end{array}$ & $\begin{array}{c}\text { Voltage } \\
(\mathbf{V})\end{array}$ & $\begin{array}{c}\text { Current } \\
(\mathbf{A})\end{array}$ & $\begin{array}{c}\text { Power } \\
(\mathbf{W})\end{array}$ \\
\hline At $2500 \mathrm{rpm}$ & 12 & 0.16 & 1.92 \\
\hline At $5100 \mathrm{rpm}$ & 12 & 0.25 & 3 \\
\hline At $9000 \mathrm{rpm}$ & 12 & 0.75 & 9 \\
\hline At $17000 \mathrm{rpm}$ & 12 & 1.9 & 11.2 \\
\hline
\end{tabular}

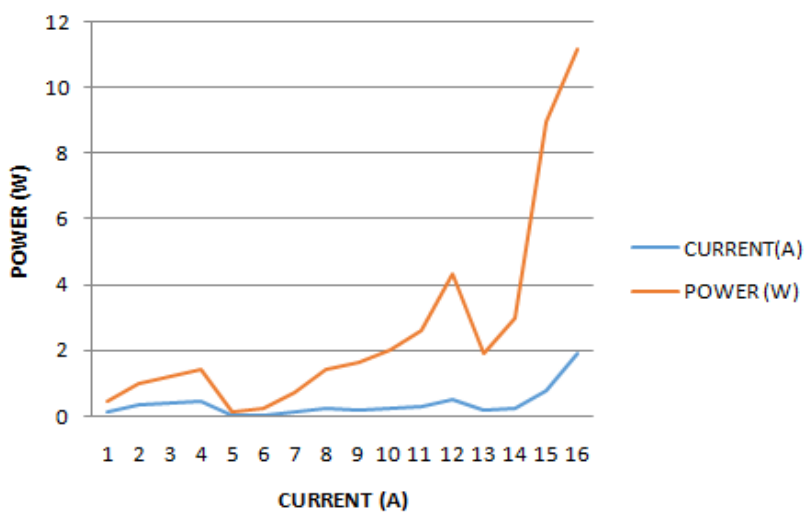

Fig. 1. Power vs Current.

In the power vs. current graph it is shown that there is increase in the power as the current of motor increases. It is also shown that between 4 to $5 \mathrm{amp}$ of current there is a drop of power and then increases till $12 \mathrm{amps}$ at a power of $4 \mathrm{w}$. After 12 amp to 13 amp there is also a drop in power and then the power increases at max current

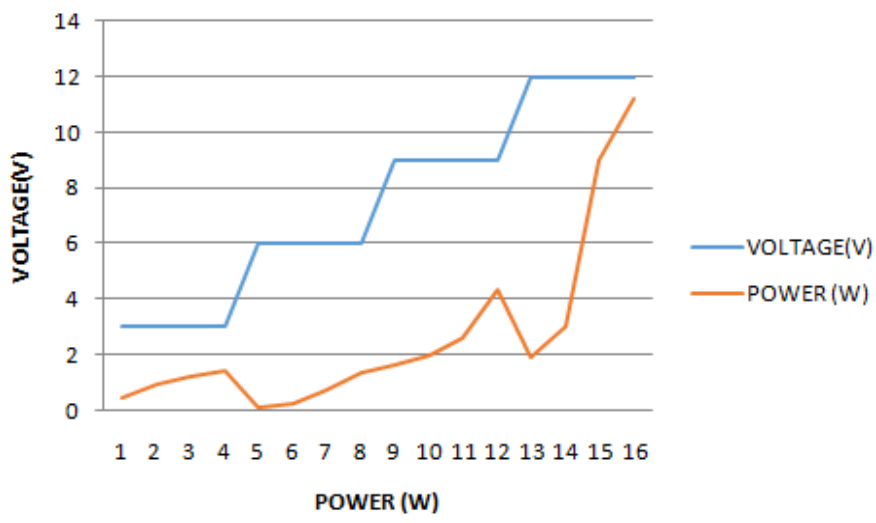
are mentioned in the above tables. According to our experiment shown in the above table we have noticed that when rpm speed of the motors are increased by keeping the voltage of the motors constant there is a increase in the induced current of motors. The induced current increases proportional to increased rpm speed of the respective motors. And the total power in the experiment is calculated by the formula $\left(\mathrm{P}=\mathrm{I}^{*} \mathrm{~A}\right)$ which is by multiplying the voltage and the induced current.

\section{REFERENCES}

1. Bailey, J., Miele, A., \& Axsen, J. (2015). "Is awareness of public charging associated with consumer interest in plug-in electric vehicles", Transportation Research Part D. Volume 36: 1-9. Retrieved http://www.sciencedirect.com/science/article/pii/S1361920 915000103M.

2. Bunce, L., Harris, M, \& Burgess, M. (2014). "Charge up then charge

3. out? Drivers' perceptions and experiences of electric vehicles in the UK”. Transportation Research Part A: Policy and Practice.Volume59:278287.http://www.sciencedirect.com/science/art icle/pii/S0965856413002395.

4. Automotive Energy Supply Corporation. (2007). Rechargeable Lithium Ion Battery. Retrieved June 15,2010,from http://www.eco-aesc.com/en/liion.html.

5. Battery Association of Japan. (2004). Recycling Portable Rechargeable Batteries. Retrieved July 8, 2010, http://www.baj.or.jp/recycle/recycle04.html

6. Kishida, Shunji, Masato Shirakata and Masaharu Satoh. (2004) "Rapidly Chargeable/ Dischargeable Batteries with Excellent Benefit

7. For Less Energy Consumption Society”. Retrieved June 25, 2010, from

8. http://www.city.sendai.jp/kankyou/kanri/icgps/pdf/6- 2.pdf

9. Lombardi, Candace. (2009). "Lithium Ion Battery Industry to Boom with Wind, Solar Power". Retrieved July 26, 2010, from http://news.cnet.com/8301-11128_3-10380239-54.html.

10. State of Michigan. (2009). "Electric Drive Vehicle Battery and Component Manufacturing Initiative". Retrieved July 19, 2010, from http://www.michigan.gov/recovery/0,1607,7-172-52952_52954-2157 74--,00.html

11. Association des Vehicles Electriques de Québec (AVEQ). (2016). Retrieved fromhttp://www.aveq.ca/.

12. Canadian Automobile Association. (2016). "Electric vehicles" Retrieved from https://www.caa.ca/electric-vehicles/

13. Cahill,E.,Shawhyde-Davies, J.,Turrentine, T. (2014). "New Car Dealers and Retail Innovation in California's Plug-In Electric Vehicle Market". Institute of Transportation Studies, University of California, https://itspubs.ucdavis.edu/wpcontent/themes/ucdavis/pubs/download _pdf.php?id=2353

14. California Governor's "Interagency Working Group on Zero-Emission Vehicles".http://www.evassociation.org/uploads/5/8/0/5/58052251/dr aft_2015_zev_action_plan_042415.

Fig. 2.Voltage vs Power

In the voltage vs. power graphical representation it is shown that at constant voltage the power increases and drops 


\section{AUTHORS PROFILE}

Rajeeva $\mathbf{H} \mathbf{S}$ has completed B. E. (Mech) from PES, Mandya, M.Tech from AIT ,Chikkamagaluru and $(\mathrm{Ph} . \mathrm{D})$ from V.T.U Belgaum. He has 6 years of teaching experience in Don Bosco Institute of Technology, Bangalore.

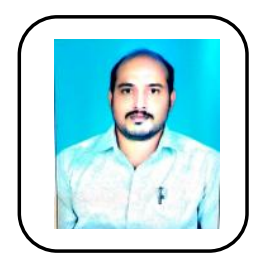

Manjunath M V has completed B. E. (Mech) from GEC, Chamarajanagara, M.Tech from UBDT Davangere and (Ph. D) from V.T.U ,Belgaum. He has 9 years of teaching experience in Don Bosco Institute of Technology, Bangalore.

Dinakar. M, and Gaurav Pandey pursuing B.E. (Mech) at Don Bosco Institute of Technology,Bangalore.

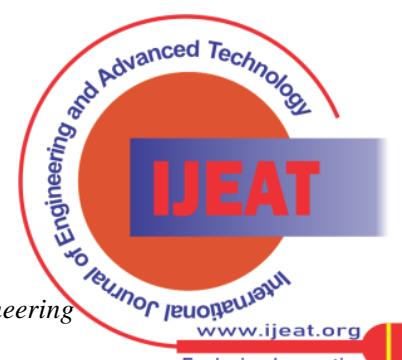

